\title{
LGBTQs in the City, Queering Urban Space
}

\author{
YVONNE P. DODERER
}

\begin{abstract}
Since the 1960s, lesbian, gay, bisexual, transgender and queer (LGBTQ) culture has developed in big cities and metropolises everywhere (not only in the West, but also in Asia, Latin America and indeed Africa). This essay examines how cities provide the spatial conditions necessary for the formation of such emancipatory movements based on identity politics and strategies which transcend binary gender dualism. The starting point of this investigation is my thesis that only urban life enables LGBTQ individuals to live their lives fully, realize their (sexual) identities, and furthermore organize themselves collectively, become publicly visible, and appropriate urban, societal and political spaces.
\end{abstract}

This essay argues that the evolution of lesbian, gay, bisexual, transsexual, queer and transgender culture over the last 50 years in many big cities has a direct correlation with urban life, the reason being that only life in the city renders possible the creation of movements focusing on identity politics and their urban spatialization. ${ }^{1}$ The queering of urban spaces is connected with questions of identity and difference, body and sexuality, as well as with everyday existence and social life, and with the economy, culture and politics of community building — indeed with the entire thematic spectrum of resistance to sex and gender normativity.

From the 1950s in the US, a gay, transsexual and lesbian movement began to develop (the latter came a little later, emerging from within the women's liberation movement) and made headlines globally with the Stonewall Riots in New York's Greenwich Village in 1969, when gays, lesbians and drag queens struck back at excessive police checks and institutionalized intimidation. Shortly afterwards, gays, lesbians and transsexuals began to mobilize in Europe too. Subsequently, many metropolises and big cities not just in the US, Europe and Australia, but also in Latin America, Asia and some African countries, have seen the establishment of a so-called lesbian, gay, bisexual, transgender and queer (LGBTQ) culture. ${ }^{2}$

This embraces activist groups and organizations which fight for equality before the law and against AIDS, and arrange culture, film and sports festivals and the annual Christopher Street Day (Gay Pride) parades. Additionally, there exist self-help groups,

1 As I have shown in research undertaken in five big German cities (Berlin, Hamburg, Frankfurt, Stuttgart and Munich), this applies to the emergence and establishment of the women's liberation movement and an urban feminist project culture (see Doderer, 2001; 2008).

2 There are various permutations of this term: some use GLBTQ; others wanting to include intersex people use LGBTI. The ' $Q$ ' in LGBTQ stands not only for 'queer' but also for 'questioning' (a more precise rendering would be LGBTQQ). 'T' stands for 'transsexual', 'transvestite', 'transgender' or 'Two Spirit' persons (instead of the ethnological term 'berdache'). Another form encountered is 'minority sexual and gender identities' (MSGI). 
advice centers, and a variety of non-commercial and commercial meeting places like clubs, discos, cafés, bars, saunas or restaurants. Furthermore, companies owned and managed by LGBTQs tailor their marketing to their own community, and many journals, TV channels and radio stations have been established to connect LGBTQ people. Last but not least, there are countless virtual networks helping LGBTQs to get in contact. A quantity of research and studies into the urban geography of these cultures has been published in recent years, most notably in the English-speaking world (see e.g. Whittle, 1994; Bell and Valentine, 1995; Ingram et al., 1997; Higgs, 1999).

Although the situation in terms of the legality of homosexuality and transsexuality or same-sex marriage varies widely from country to country (even today, homosexual and transsexual practices are punishable by imprisonment or even death in certain countries), some researchers speak about 'the global gay' and the 'internationalization of gay identities' (Altman, 2001) in recognition of this broad LGBTQ culture.

On the one hand, within the framework of a Westernized and US-coined modernism (and postcolonialism), this notion has to be read critically. On the other hand, this conclusion rightly acknowledges the global networks active in the fight for equal rights and societal recognition, plus a wider intensive international exchange among LGBTQ communities. It is no coincidence that LGBTQs prefer to live in bigger cities, especially in intra-urban areas, and also that in such urban quarters LGBTQ culture is closest to the mainstream public. In comparison to rural communities, social and familial control functions to a lesser extent in cities, and more opportunities exist to meet other LGBTQs and consequently to pool together.

City life broadens horizons and challenges dominant gender arrangements - a scenario which is not only important for women (as described by Elisabeth Wilson, 1992) but also for LGBTQs. The urban domain allows for difference, whilst the queering of urban-societal spaces questions dominant gender regimes. Queering urban space means building an emancipatory public and emerging from the shadows of a mainstream society which hitherto denied and negated urban-societal reality (because queerness exists in all societies and always has, and queerness is part of human sexuality and identity even if it is oppressed or if it is named and lived in different ways). The queering of urban-societal spaces includes a phase of resistance, precisely because the LGBTQ individual or community resists against the normativity of sex, gender and heterosexuality. This resistance can be performed using various strategies: not only as 'other' sexual practice and orientation but also through dress styles, habits and language, community building and political action. Queering urban space can be carried out in a subtle or offensive manner, it can be performed gently or loudly. Queer signs can be visible for others but they can also be unreadable. Some LGBTQs live their identity and sexuality openly and 'on the offensive' in their everyday lives, others switch between outer 'normality' and queer identity, coming out only at specific places and times. But this moment of resistance which is inherent in self-definition as LGBTQ is not to be mixed up with the fact that the normativity of sex, gender and heterosexuality is fragile in the first place — despite the media constantly producing heteronormative and gender-differential images about 'femininity' and 'masculinity', family life and heterosexual sociality. This is not changed by the occasional appearance of LGBTQ lifestyles in the media, because TV shows like 'Queer as Folk' or 'The L Word', although appreciated by LGBTQs, are awash with heterosexualconnoted patterns of action and characters. Mantling urban spaces with billboards, the advertising industry also uses a visual language which reverts to these stereotypes. But the normativity of sex/gender goes further than the visual distribution of mostly unrealistic projections and sugar-coated surrogates, because this normativity is primarily based on the naturalization of a binary sex/gender regime defining gender differences and heterosexuality as biologically anchored, and understanding 'other' identities as deviance. Even in 'modern' and 'enlightened' societies, one can detect an inertia of the binary order of sexes and gender that is deep rooted in the psyche of every individual - let alone the ongoing structural inequalities and differences 
pertaining to the category of gender, in combination with other categories like class, race and age.

Clearly, gender circumstances are not completely static, but changeable and adaptable to particular societal and economic developments. Because of this adaptivity, the efficacy of the order of sexes and gender varies depending on the contemporary societal relations and the status of the individual. But to live as gay, lesbian, queer, transgender or intersexual still collides with dominant sex/gender orders, which remain prevalent in virtually all societies today (albeit in slightly different forms and variations) because 'other' identities and their ways of living are read more or less openly as deviance: here the spectrum ranges from conniving tolerance, anti-LGBTQ prejudice, ignorance and discrimination, to open suppression and violence. Even in liberal circles (e.g. in the world of the arts and culture, or in the film, fashion or music industry), heteronormative gender images still dominate. Although queer life can be established in these fields, it is not necessarily communicated outwards. To reveal oneself as queer still generates irritation and insecurity; in case of doubt the issue is simply excluded from discourse. Even in countries where same-sex marriages are legally recognized or where politicians have come out, the confrontation with a 'real' LGBTQ individual evokes a questioning of heterosexual identity and normativity. Sometimes such a meeting is a confrontation with unfulfilled wishes and desires, because the assumed naturalness of heterosexual gender identity is less solid than suggested. For example, it is not uncommon for women to live with men because they profit economically and socially from the relationship; to enter into a relationship with a lesbian or queer person might evoke precariousness and implies the danger of societal non-recognition (many men are far from open about their gayness for the same reason). Meanwhile, a lot of LGBTQ people try to project themselves as being as 'normal' as possible, understanding their (sexual) identity as a private issue and thus propagating the recognition of same-sex marriage. Same-sex marriage offers a legalized and therefore secure status; the foundations of the sex/gender regime are not challenged by it.

It becomes apparent that the term LGBTQ not only represents a scope of different sexual orientations, but also summarizes very different political positions, including Right-wing radicalism. These positions range from the understanding that 'my sexuality is my private issue' over identity politics ('I am gay — and that is fine', as the mayor of Berlin, Klaus Wowereit, stated publicly in 2001, or the postulate of a 'Queer Nation') to queer, gender-variant and transgender politics focusing on the transgression of the category of sex/gender in a sustainable way. Against this background it also becomes apparent that queering not only means the irritations, conflicts and crises arising from the normativity of sex/gender (although they can be part of queering). At this point, the cutting edge between feminist and queer politics becomes evident. Understanding 'to queer' in a Leftist and feminist political sense, means to go a step further in the sense of a conscious resistance against and traversal of sex/gender regimes with the notion and the demand to change them. But in contradiction to a feminism focusing on the differences between women and men (and trying to strengthen women and femininity), queering focuses on a general questioning of the category of sex/gender (including the questioning of the legitimization of sex and gender by biology) with a view to deconstructing this category, not only on a theoretical level but also on a practical level. This intention is expressed by the term transgender, especially because 'trans' in this context means to bypass the notion of sex and gender. As a political option, this concept is perhaps too diffuse and unmanageable. This can be seen also in the use of the term 'queer', because various possible identities are subsumed under this umbrella without necessarily activating its political aspects. Nevertheless these two terms are important and necessary, because their contemporary use represents a critique of identity politics' mechanisms of exclusion. Additionally, whilst the adjective 'feminist' still retains a negative connotation for some, it can be seen that the enforcement of queer, transgender and intersex needs (e.g. in language) is very complicated and has the potential to raise hackles. 
Even if sex/gender regimes in almost all areas of contemporary societies remain very fixed (especially on structural levels), they have become more fluid in highly industrialized countries in the course of being adapted to the demands of globalized and neoliberal capitalism. The diversification of economic target groups mirrors changed ways of living, especially in cities because here the traditional nuclear family is no longer the dominant form of lifestyle. In capitals and bigger cities a lot of people live as singles, in apartment-sharing communities, in same-sex relationships, or are single parents. This variety of lifestyles, way beyond the classic nuclear family, is not only the result of individualization, higher life expectancy, higher divorce rates and shrinking birthrates, but also an expression of personal requirements arising from greater self-determination, emancipation and freedom, aspects that are of huge importance, especially for women and LGBTQ people. To have the chance to live in one's own apartment means to have a retreat of sorts, a shelter offering a distinct space from life outside. Having one's own living space means having the chance to self-determine body, sexuality and identity issues. But city apartments are usually expensive, although housing- and real estatemarket structures differ from country to country and from city to city. In Europe, Berlin still has the lowest, and London the highest, rents. In addition, income differences and unemployment exacerbate access to the housing market and to corresponding preferred residential areas, so gender, class and racial differences play an important role for LGBTQs as much as for other groups. There are some significant negative factors associated with living alone in a city, including isolation, a lack of social connection and accommodation inadequacies, which for older single LGBTQs become increasingly important. However, city and urban life opens up many possibilities for LGBTQ people: to submerge and indeed emerge within the urban anonymity, to escape the bonds of controlling family, to enjoy urban nightlife, to share experiences with other LGBTQs, to celebrate and to discuss together, and to organize political action.

City life and its habits make it easier to connect with other LGBTQ people and to establish LGBTQ community and culture. With regard to these communities, Judith Butler speaks of alternative and extended forms of kinship, of voluntary kinship, i.e. structures of engagement and relationships beyond traditional familial-biological legitimized entities. Such alternative kinship relations are created by sexual contacts, intimacy, friendship and the creation of LGBTQ communities. Therefore, queering urban spaces embraces not only issues of self-determined lifestyle and habitation by the LGBTQ individual, but also the establishment of communities defining themselves via voluntary kinship, social and cultural life (and indeed political demands).

It is much easier to establish and remain in contact with corresponding LGBTQ social scenes in metropolises like San Francisco, New York, Sydney, Tokyo, Berlin and London, and in bigger cities like Boston, Toronto, Hamburg and Barcelona, than it is in smaller cities or in the countryside. But expansions, infrastructures and resources of LGBTQ cultures depend on the local, social and political situation of each city. In some of these cities, extremely comprehensive queer urban areas and quarters have been established with significant LGBTQ populations. The best known of these districts is 'The Castro' in San Francisco.

Despite the possibilities that city living creates, it still remains hard to organize oneself beyond an individual level, to appropriate urban spaces and to establish LGBTQ culture. In addition, the internet today opens up new possibilities; for example, gay cruising in urban parks, streets and public toilets has been largely replaced by cruising in virtual space. In the internet age, visiting gay bars, discos, saunas, sport studios and porn cinemas has declined - instead LGBTQs prefer to meet in private homes (for lesbians, cruising never was on the agenda).

This trend of a retreat into private life and the de-collectivization it brings with it is exacerbated by the fact that life in cities - even in the US and in Europe - is becoming increasingly difficult. Rising rents and real estate prices transform residential property in inner cities into a resource which for financially weak LGBTQs becomes ever harder to obtain. As already mentioned, economic differences naturally 
apply to LGBTQ communities too. This can be seen when examining the establishment of queer-friendly urban districts. Looking closely, it becomes obvious that gay white men in particular can afford to rent or buy apartments and spaces in urban quarters of interest to LGBTQ communities (this kind of urban appropriation includes effects of gentrification too, as already seen in 'The Castro'). Very few lesbians, queer females and transgenders of my acquaintance own apartments. Most live in rented apartments (and the rent consumes a large chunk of their income). ${ }^{3}$ There does, however, exist a 'lesbian middle class' who can afford expensive apartments or can pay higher rents - but statistically (and very notably so in Germany) there remains a wide gap between the income of women and men. This not only makes it more complicated to find affordable living space, but also to rent spaces in which to meet and organize events. Non-commercial LGBTQ initiatives in particular depend on a choice of spaces being not only affordable, but also accessible and amenable to the LGBTQ culture. These changes in the real estate and housing market take place in the context of waves of an 'urban arms build-up' (municipal politics is exclusively geared to the interests of financial capital). Such developments can be observed around the globe in almost all major cities. Investment is inevitably concentrated in private housing and urban development for a solvent clientele. The colorful designs, brochures and advertising campaigns invariably focus on young, prosperous and successful heterosexual couples and nuclear families, and sometimes on professional singles. Other lifestyles, other forms of urban and architectural designs (e.g. mixed-use urban quarters with affordable small commercial units and good connections to public transport) are not found in this kind of planning. Instead, urban segregation is enforced and enclaves for the wealthy are established. This also has effects on pre-existing queer urban areas, because this urban arms build-up goes hand-in-hand with a normative homogenization unable to accommodate deviation of any kind. In the 1980s, many cities began to put into practice the 'broken windows' theory (i.e. zero tolerance of petty offences, loitering and public begging); this has evolved into a wholesale clean-out of 'unwanted groups of people' in numerous inner-city areas, a process that saw the wiping out of queer scenes not in keeping with the image of the assimilated and 'normalized' white gay or lesbian. Frank Leon Roberts describes, for example, the urban history of Christopher Street Pier in New York's West Village, and the systematic displacement of queer black and Latino youth in the frame of an urban 'quality of life' program (Roberts, 2003). (It is worth acknowledging that LGBTQ people continue to live in these 'cleaned' urban quarters, and might even participate in campaigns against unwanted marginal groups. To be LGBTQ is no guarantee of a critical and self-reflexive position and way of thinking.)

What such an urban policy precludes is the appropriation of urban spaces by scenes and communities beyond the mainstream (be they heterosexual or homosexual), thereby preventing so-called ethnic or/and poor minorities in particular from realizing other ways of living. In the long run, such an urban policy fossilizes life in the city, excluding any possibility of progress based on productive difference, on heterogeneity as well as on homogeneity of smaller groups with their own spatial demands and an enabling of emancipatory liberty. As Henri Lefebvre (1991: 416) stated: 'Moreover - and more importantly - groups, classes or fractions of classes cannot constitute themselves, or recognize one another, as "subjects" unless they generate (or produce) a space'.

This right to the city and urban appropriation no longer resonates for all urbanites. A capital like Paris for example is already, in the truest sense of the word, turned into stone. Here non-profit initiatives no longer have a chance to establish themselves, which has effects on LGBTQ people. Elsewhere in Europe, however (most notably in Berlin), there exists a significant number of non-profit LGBTQ spaces; only in such places can a

3 Contrary to other European countries, in Germany the rental market predominates. In countries like France, Italy or Spain the condominium predominates, with the effect that young people are obliged to live with their parents and family, usually until they marry. 
colorful non-profit urban LGBTQ culture and public come into being (in Berlin's case making it very attractive to LGBTQ tourists in particular).

But life in the city also becomes harder because precariousness and informalization of paid labor (as well as unemployment) is on the rise. This development not only has an impact at the economic level; it also complicates living openly as LGBTQ, because in competitive situations 'deviances' of any kind are less accepted. In addition, more onerous job requirements and a greater need for compliance result in less time for political activities, as everyone (including LGBTQ people) needs more time simply to ensure survival. Here, pre-existing differences are exacerbated, because poorer LGBTQ $\mathrm{s}$ in particular must invest more to organize their lives, and often receive reduced social and substantial support from their relatives.

In spite of all this, the city and urban life will remain the preferred domain for LGBTQ people in the future. The all-important question is: what will the urban lives of LGBTQs look like in 20 or 30 years' time? Which societal and political forces will assert themselves in urban policy: forces wanting a clean, economically exploitable, nuclear family-friendly, pacified but de-democratized city; or forces which genuinely recognize 'queer' life, not only as self-evident and as an integral part of urban life, but also as enrichment for the city. As a final (and crucial) point, it should be noted that LGBTQ communities need to look to themselves to satisfactorily answer this question.

Yvonne P. Doderer (ypdoderer@transdisciplinary.net), Office for Transdisciplinary Research and Cultural Production, Stuttgart, Germany.

\section{References}

Altman, D. (2001) Rupture or continuity? The internationalization of gay identities. In J.C. Hawley (ed.), Postcolonial, queer: theoretical intersections, State University of New York Press, New York.

Bell, D. and G. Valentine (eds.) (1995) Mapping desire: geographies of sexualities. Routledge, London.

Doderer, Y.P. (2001) Urbane praktiken. Strategien und raumproduktionen feministischer frauenöffentlichkeit. Vannerdat \& Monsenstein, Munster.

Doderer, Y.P. (2008) From yesterday to tomorrow. The production of women's and lesbians' urban public in Germany. In M. Grzinic and R. Reitsamer (eds.), New feminism: worlds of feminism, queer and networking conditions, Löcker, Vienna.

Higgs, D. (1999) Queer sites. Gay urban histories since 1600. Routledge, London and New York.
Ingram, G.B., A. Bouthillette and Y. Retter (eds.) (1997) Queers in space: communities/public places/sites of resistance. Bay Press, Seattle.

Lefebvre, H. (1991) The production of space. Blackwell, Oxford and Malden.

Roberts, F.L. (2003) Disruptive spaces/ disruptive cultures: 'quality of life', queer space and the history and gentrification of the Christopher Street Pier. Paper presented at the Gallatin School of Individualized Study, New York University, 6 May.

Whittle, S. (ed.) (1994) The margins of the city - gay men's urban lives. Ashgate, Aldershot.

Wilson, E. (1992) The sphinx in the city: urban life, the control of disorder and women. Virago, London and University of California Press, Berkeley.

\section{Résumé}

Depuis les années 1960, les grandes villes et métropoles, non seulement de l'Europe, mais aussi d'Asie, d'Amérique latine et d'Afrique, ont vu se développer une culture glesbienne, gai, bisexual, transgender et queer. Cet article étudie quelques aspect de la relation entre ces villes qui est une condition pour la formation de ce type de mouvements d'émancipation fondés sur la mise en question de la bipolarité sexuelle. Mon étude repose sur la thèse que c'est exclusivement dans la cadre de la vie urbaine que ces identités (sexuelles) peuvent se manifester et s'organiser afin de devenir visible sur la place publique et d'investir l'espace urbain, social et politique. 